\title{
RE-ENCOUNTERING TRADITIONAL INDIGENOUS ACTIVITIES THROUGH A PSYCHOSOCIAL INTERVENTION IN SUNRISE COMMUNITY RE-ENCOUNTERING TRADITIONAL INDIGENOUS CUSTOMS
}

\author{
Mayara dos Santos Ferreira \\ Marcelo Gustavo Aguilar Calegare \\ Cláudia Regina Brandão Sampaio \\ Federal University of Amazons, Brazil
}

\section{Ornette D. Clennon}

\section{Manchester Metropolitan University, United Kingdom}

\begin{abstract}
This article makes a reading and reflection of a psychosocial intervention completed at Sunrise Community (SRC), a multi-ethnic indigenous settlement located in Manaus, Amazonas, Brazil. Alongside non-indigenous residents there are 12 indigenous groups represented. Through community social psychology approach and Participatory Action Research, weekly visits were made for five months. Interviews, meetings, and informal conversations with leaders and residents were recorded in field diaries. Among the concerns residents had were communication difficulties and the distancing of traditional practices that are associated with identity issues and historical inter-ethnic conflicts that mark relations in the SRC. As a result, the community held a Meeting of Ethnic Groups to gather members of SRC and other indigenous settlements for a day of celebration, to reencounter traditional customs and practices. The intervention team acted as facilitator, orchestrating reflections on the roles, struggles and autonomy in the SRC and suggesting a horizontal model in the interactions. The organization and preparation of the celebration increased the interaction among the residents. However, the psychosocial complexity of the community has revealed other issues, such as: different forms of participation and the ambiguity of identity markers. Reflections on postcolonialism and power relations weave important considerations into the findings, especially to reflect on the political dimension in claiming the rights of these groups.
\end{abstract}

\section{Keywords}

Indigenous Community; Community Social Psychology; Psychosocial Intervention; Participatory Action Research.

\begin{abstract}
RESUMO
Este artigo faz uma leitura e reflexão de uma intervenção psicossocial realizada na Comunidade Sol Nascene (CSN), um assentamento indígena pluriétnico localizado em Manaus, Amazonas, Brasil. Ao lado de residentes não indígenas, há 12 grupos indígenas representados. Por abordagem da Psicologia Social Comunitária e Pesquisa Ação Participativa, visitas semanais foram feitas por cinco meses. Entrevistas, reuniões e conversas informais com líderes e residentes foram registradas em diários de campo. Entre as preocupações que os residentes tinham, havia: dificuldades de comunicação e o distanciamento de práticas tradicionais associadas a questões de identidade e conflitos interétnicos históricos que marcam as relações na CSN. Como resultado, a comunidade realizou um Encontro de Etnias para reunir membros da CSN e outros assentamentos indígenas para um dia de celebração, para reencontrar os costumes e práticas tradicionais. A equipe intervencionista atuou como facilitadora, favorecendo reflexões sobre os papéis, lutas e autonomia na CSN e sugerindo um modelo horizontal nas interações. A organização e preparação da celebração aumentaram a interação entre os residentes. Todavia, a complexidade psicossocial da comunidade revelou outras questões, tais como: diferentes formas de participação e a ambiguidade dos marcadores identitários. As reflexões sobre o pós-colonialismo e as relações de poder tornaram possível tecer considerações importantes nos resultados, especialmente para refletir sobre a dimensão política na reivindicação dos direitos desses grupos.
\end{abstract}

\section{Palavras-chave}

Comunidade indígena; Psicologia Social Comunitária; Intervenção Psicossocial; Pesquisa Ação Participativa.

\footnotetext{
Correspondence about this article should be addressed to Marcelo Calegare, Universidade Federal do Amazonas, Av. Gen. Rodrigo
} Octávio 6200, Bloco X, Setor Sul. Coroado I, Manaus/AM, Brasil.69080-900.Email: mgacalegare@ufam.edu.br 


\section{REENCUENTRO DE ACTIVIDADES INDÍGENAS TRADICIONALES A TRAVÉS DE UNA INTERVENCIÓN PSICOSOCIAL EN LA COMUNIDAD DE SUNRISE REENCUENTRO DE ADUANAS INDÍGENAS TRADICIONALES}

The migration of indigenous peoples to urban environments in Latin America has been seen there for about 70 years (Estrada \& García, 2016). The reality for these people in the city is usually associated with stereotypes, situations of marginalization and social inequalities. This is mainly confirmed by the hierarchy of ethnic identities that have been happening over time. A common characteristic of their organization in city environments is the formation of indigenous groups or associations, which have been one of the main instruments of political mobilization and demand for improvements.

In Brazil, the 2010 Demographic Census estimated that there are 896,900 indigenous people, from 305 ethnic groups. The state of Amazonas has the largest number of indigenous people: 168,680 from 93 ethnic groups (Souza, 2013). Some of them reside in the state capital, Manaus. The official estimate is that there are 3,837 indigenous people, but unofficial data from the Coordination of the Indigenous Peoples of Manaus and Environs (COPIME) indicate the presence of 30,000 indigenous people from 34 ethnic groups. There are many indigenous organizations in the city, with the objective of preserving culture and fighting for social rights (New Social Cartography of the Amazon, 2018).

One of the indigenous settlements established in a Permanent Preservation Area (PPA), located in the northern part of Manaus, is known as Sunrise Community (SRC). The community area measures approximately 6.7 hectares. However, taking into account surrounding green areas, it is more than 8 hectares. The population estimate for the year 2018 is that 150 families live in SRC, totaling 600 people. The indigenous population of the community is composed of 12 different ethnic groups: Apurinã, Baré, Dessana, Kaixana, Kambeba, Kokama, Miranha, Munduruku, Mura, SateréMawé, Tariana, and Tukano. The indigenous inhabitants number around 400 people. The remaining 200 residents are non-indigenous. It is, therefore, a predominantly indigenous multi-ethnic community, in the context of the city.

Areas such as that occupied by SRC are also called 'invaded areas'. This terminology, however, follows the point of view that criminalizes and stigmatizes social movements that occupy spaces in search of the right to housing. The SRC area, being a PPA and covered by a fragment of forest, according to the Forest Code (Brasil, 2012), belongs to the Municipal Department of Environment and Sustainability. In June of 2013 the occupation of this area began by members of the Miranha ethnic group (Rosa, 2016). It was the intention of the first occupants of the area to establish it as a regularized indigenous settlement, an agenda that is still pursued by the current community leadership.

The arrival of new indigenous members resulted in a more robust collective formation of the community. Leaders divided the community space by aggregating different groups, according to their ethnic affinities. This process of organization generated the name of the streets of the place: Apurinã Street, Baré Street, Dessana Alley, Kaixana Street, Miranha Avenue, and Tukano Street. This collective populating also boosted the election of the first cacique - a community and political leader of an indigenous group - of the Mura ethnic group.

The SRC underwent a new transformation when the area became occupied by non-indigenous people, disrupting the initial system. There are still many indigenous residents self-identified by the ethnic classification corresponding to their street address. However, among the current nonindigenous residents, some are not even aware of the reason for the street names and their purpose. Because SRC members considered that the community leader had taken an opposite direction to the ideal of the community by allowing non-indigenous people to live in his personal circle, he was soon removed from office. A new election was held and the chosen leader, chief of the Kaixana ethnic group, held office for three years guiding community demands, mainly for infrastructure improvements and reforestation. At the beginning of 2018, this cacique resigned the position. A new election was held with a leader from the Dessana ethnic group taking over.

However, the common element that creates a social bond between residents, whether they are indigenous or non-indigenous, is being placed in a context of social disadvantage, marked by marginalization, precarious social services and vulnerability. Therefore, throughout the establishment 
of the SRC, with the purpose of organizing the demands and political mobilization of its residents, the Community Association "Co-ordination of the Settlement of the Indigenous People of Sunrise Community" (CAPISOL) was established, which, despite its name referring only to the indigenous groups, included demands of the whole community such as surfaced roads, basic sanitation, street lights, public security and other aspects of improved infrastructure.

When Ferreira (2019), conducted research in the same community, she recorded residents' statements that affirmed that, irrespective of ethnicity, residents shared mutual interests related to the rights of the community which brought them closer together:

Yes, because it's the same. It's practically the same message right, and also because if it's for one it's for everyone. The rights, are... for everyone. For all ethnicities and for all the residents here. (Community Member, woman, 39 years old).

Yes, everyone. All of them, because we're the same. Although we speak a language, I'm speaking Portuguese, we talk a little different from each other, but they're all the same just the name changes. We're all related, right? (Community Member, woman 41 years old)

And we're all here, being part of the same group right, of the same movement. We're here, living in the same place, right. That's why (Community Member, male, 35 years old) (p.50).

Initial contact between community leaders and members of the Laboratory of Social Intervention and Community Development (LABINS) at the Faculty of Psychology, Federal University of Amazonas (UFAM), took place in early 2016. The cacique sought out one of the professors, asking to help the community, reporting that residents were experiencing difficulties related to violence, lack of public safety and disunity between them. We visited the community a few times and met CAPISOL's leaders, motivated both in offering help and also knowing the community problems, so we could try together - University Team and community - to seek some possible solutions. Together with the cacique, we made some agreements about our presence in the community: we would bring students from the 'Community Social Psychology' discipline in the second half of 2016 and again in 2017. The objective of the first visit (in 2016) would be to know the local reality and, from the knowledge generated, propose some intervention through an extension project, to be carried out on the second half of 2017. In addition to the intervention we proposed to carry out research projects that would take place from the second half of 2016 until the end of 2018. The intention of the projects was to gather qualified information about the Community reality. Thus, the period of permanence of the team in the community occurred between 2016 and 2018. However, it is worth noting that the focus of this article consists of the intervention project, which was prepared jointly by LABINS and community members, resulting in activity records in reports, in each of its stages, different from the research subsequently performed.

On this basis this article makes a reading and reflection of the psychosocial intervention carried out by members of LABINS with SRC residents. The purpose of the LABINS team in the intervention project was to familiarize the external agents with the internal agents and the daily life of the community, to raise their problems and to draw up an intervention plan. The reflections come from the register on the field diaries and the articulation with community psychology theories. Principles of community social psychology were followed, a field of knowledge and action that allows us to understand the psychosocial perspectives of community groups and to consider the pluriethnic essence and the characteristics of the settlement's formation; reflect on political and ethical aspects of people's lives in the community, generate awareness, engagement and participation; and from this, the transformation of the local reality (Freitas, 2003; Góis, 2005; Montero, Sonn, \& Burton, 2017). In addition, we propose to make some reflections that we consider relevant to thinking about some of the points of tension that the contemporary context presents to us, mainly related to the issues of interculturality when less strengthened ethnic groups are involved.

\section{Method}

The team followed the precepts of Participatory Action Research (PAR) (Góis, 2005), which articulates theory and practice, including research, extension and intervention ind four steps spelled out bellow. It involves agents from inside and outside the community in the elaboration of knowledge about the local context, combining scientific methods and notes with popular knowledge in problem 
solving (Freitas, 1998). The members of the LABINS team are here called external agents, and members of the community, internal agents.

The steps of PAR along with each procedure were as follows:

A) Familiarization and formation of relationships between internal and external agents. As previously related, we were in the community with different teams between 2016 and 2018: undergraduate discipline students; an intervention project team and a team of researchers. For the intervention project focus of this article, we carried out routine weekly visits to the community on Saturday morning from August to December 2017. The LABINS team consisted of ten people: one teacher/advisor, eight undergraduate students (from Psychology and Social Work), and one Master's degree student in Psychology. Community members included 10 people from CAPISOL (adult men and women), with intermittent participation of their families (husband or wife, children, uncles and grandparents). At times there was participation of other people in the community, when they were available. During this stage, we circulated throughout the community, visited residents in their homes, participated in parties in the community and had many informal conversations at CAPISOL headquarters, with the aim of becoming familiar with internal agents. At no time did we record formal interviews, which is why we will not present in the article quotes from residents, but only data from our records in the field diary.

B) Definition of the problem. Once good relationships had been established between us and the residents, we gradually systematized their complaints, needs and potential ways to solve problems. In October 2017 we held a meeting where we discussed all the problems raised and decided together which we would be able to propose an intervention on.

C) Intervention planning. Tasks were divided between members of the university intervention team and the community members, from the mutual decision to do, when, how and for what purposes. In this article we also add the reflections of the LABINS team to perform the intervention.

D) Self-evaluation (feedback). It was performed continuously throughout the intervention process, especially at the end of the intervention project. We also add in this text our reflections about the whole process of PAR.

In the next section of the article, we will first present the data produced initially in step "A" and "B" (familiarization and definition of the problem). Next, we describe the results and discuss the intervention performed in stage "C" (intervention planning) and "D" (self-evaluation/feedback). Then, we propose the reflections generated in these steps through the perspective of rights discourse, postcolonialism and decolonialty, ending with some considerations about this intercultural scenario and the participation of the intervention team.

\section{Steps A and B: Familiarization and Defining the problems}

The problems identified through dialogue between internal and external agents ranged from infrastructure to psychosocial issues. The problems raised were: lack of basic sanitation; irregular water and electricity supply; unsurfaced roads; legal ownership of land; accumulation of garbage in open areas; prejudice / discrimination; resistance to indigenous self-identification; difficulty in teaching the mother tongue; drug trafficking; excessive use of alcohol and other drugs; reports of domestic violence; poor access to healthcare in nearby facilities and disagreements with local churches.

Regarding the infrastructure, residents complained about unpaved streets, irregular water, electricity connections and sanitation, all of which are considered factors that make housing difficult in this space. It is interesting to note that previous leaders had the initial intention of keeping the settlement as similar as possible to grassroots communities, as found in indigenous villages. So, for example, the streets would be unpaved. However, such characteristics did not prevail, a reason attributed to the inclusion of non-indigenous residents, according to the leadership.

In negotiation with the internal agents, we realized that we could not act on all the problems raised, restricting ourselves to those that were within our reach. Therefore we decided to work on the main psychosocial issues identified: the difficulty of communication between the residents and the decline in indigenous cultural practices. 


\section{Difficulty of communication}

The central psychosocial problem highlighted was the difficulty of communication. The leadership indicated the community relationship is marked by a certain disharmony among the residents, which causes discomfort and setbacks in collective political mobilization. Leaders assert that this has corroborated a lack of participation of community members in meetings or actions proposed by the Community Association, which was also perceived by the intervention team. Residents mostly do not attend community meetings. Reports of the interviewees point out that they do not know the meeting schedule, others say they can not be present because of work commitments. All this has resulted in lack of unity and disengagement, according to the leadership. However, we consider other elements that affect issues of participation, which were not addressed by leadership, but which we consider relevant. These will be pointed out later.

The discourse of many residents reveals no identification with indigenous identity, even though they claim to have such a lineage. This may be associated with the propositions of Bernal (2009) in what is termed the "formal sense collector." This is defined as a game of classification between indigenous and non-indigenous people, which in a relational dimension, functions as a zone of tolerance for groups with distinct identity patterns. In this area, it is understood that each person, according to the social moment, brings the category of identity that is relevant. This game provided by the understanding of "being or not being indigenous" is seen by the leadership as something that promotes a lack of cohesion with regards to the organization for claims. Non-indigenous residents, on the other hand, feel uncomfortable about the possibility of losing their homes after the settlement of SRC as indigenous land. This may indicate a motivating factor for complaints to the Community Association leadership and distancing from community causes.

Therefore, failure to attend meetings may be about much more than "lack of interest" as the cacique put it. This can be a factor directly related to the distinct interests among the inhabitants of different ethnic groups and also of the non-indigenous residents. The interests of the subgroups may differ substantially from the main guidelines of the Community Association, resulting in a tension. In addition, we also expressly realized that many residents have an interest in maintaining the community as secure land for housing, not necessarily as a "territory".

There is an extensive discussion regarding the demarcation of indigenous lands, which involves the reflection on the concepts of land and territory in Brazil. It is necessary to understand that the concept of "land" refers to a political-juridical dimension instituted by the State for the demarcation of indigenous lands, in a sense of geographical space (Gallois, 2004). "Territory" refers to a wide field of experience, relationship, culture - taking into account its specificities - in its contact with space, and exerts a representation mechanism (Fernandes, 2009). Thus, many of the objectives related to legalization of land may also encounter issues such as this, which sometimes go unnoticed in the intercommunity relationship.

The team also identified that historical conflicts, including cosmological conflicts between ethnic groups due to power struggles and symbols, appear to contribute to the disintegration and lack of dialogue among community residents. Among the aspects that corroborate this idea are the uneven dynamics among residents, which is expressed in the conflict between community and leadership. In this respect the studies made by Higuchi, Calegare and Freitas (2013) show that such conflicts remove and disrupt many community references from traditional (grassroots) communities, which are built on a bond-based sociability where the sharing of spaces and activities provides a community experience ruled by mutual support and solidarity. In this sense it will be plausible to think that, like the example provided by Câmara (2008), the loss of the harmony may be the basis of the setbacks experienced by $\mathrm{SRC}$, especially in the community struggles, resulting in a loss of collective effectiveness.

\section{The detachment from indigenous cultural practices}

Another psychosocial problem raised by the leadership, equally important as the diffculty of communication and, possibly related to it, was the detachment of the community from indigenous traditional practices. Community leadership has, as one of its priorities, the recovery of cultural aspects that seem to be absent in the community's way of life. According to the cacique, the denial of identity begins with the removal of traditional indigenous practices, as a way of separating indigenous 
identity from actual self-identification by indigenous people in urban contexts. It therefore acts as an annuler of ethnic identity. The disuse of indigenous accessories and the low adherence to the execution of indigenous practices and rituals are seen, in this perspective, as a way for indigenous people to insert themselves and be part of the urbanized physical and subjective spaces present in the city. This has profound implications that will be discussed later when looking at processes of decolonialisation.

The problem raised by the cacique with regard to the removal of these cultural references is that community demands for an indigenous settlement also depend on the local residents' engagement and to make themselves known as indigenous, which has been hampered by this identity disassociation. The issue opens reflections on the historical processes of indigenous identification in a city.

\section{The meeting of ethnic groups}

\section{Steps C and D: Results and Discussion of the Intervention}

The psychosocial intervention carried out by the LABINS team arose from many reflections and discussions with the community. The intention was to encourage residents and leadership to formulate an action that they considered significant for the community, which in this case, as demanded by leadership, was based on the possibility of re-engagement with practices and traditions. We organised these activities around Corntassel's (2012) notion of "resurgent" activities.

The results of the intervention were relatively positive, since we perceived the autonomy of the community through its organization in support of this action. The action was built in partnership between the LABINS team, community leadership and the community. Its intention was to promote a rediscovery of traditional practices that, until then, had not been carried out in SRC, in addition to enabling interaction among the residents. In an autonomous way, the leaders (cacique and deputy cacique) arranged what they called the "Meeting of Ethnic Groups" which was held four months after the intervention project in the community started its activities.

The leadership devised and organized a day of celebration, with the purpose of promoting a meeting among indigenous parentes, or "relatives" - a term used by the indigenous peoples to refer to indigenous people who might, or might not, have consanguineous bonds - and to reunite residents of the SRC and other indigenous settlements in Manaus, in much the same way Simpson's (2008) fourth point advocated. The invitation to participate in the festivities was also extended to non-indigenous residents of the community. The party included presentations by indigenous groups from other settlements in Manaus. The guests included the groups Bayaruá and Waruna Kokama who sang and danced, in ritualistic choreographies and musical presentations. The leadership and the people of the SRC organized the production of drinks and traditional foods (caxiri, pororoca, baked and cooked fish, etc.) and handicrafts.

Morigi, Laroque, Magalhães, Gomes, and Barden (2013) describe that in cultural memory, symbolic legacies are reconnected to by the practise of rites, celebraions, and other mnemonic and dynamic items. Cultural memory refers to events of the past but goes beyond an experienced memory. It also refers to objects and practices that become symbols, and evidence an identity representation (Bojić, 2015). Thus, it would promote a reunion embodied by the traditional practices hitherto only connected to by memories, or even forgotten. The Meeting of Ethnic Groups facilitated this "resurgent" activity through the indigenous accessories used, as well as artistic and cultural manifestations.

The community leaders organized all the festival's publicity: the invitation to attend was by an audio message backed by indigenous themed music, broadcast by Rádio Tribos do Norte, and voiced by reporter Kaina Mã. The production of this audio by the leadership has a social representation, which goes beyond promoting the autonomy of the group in the structuring of actions in favor of the community. This production also allows the enhancement of ethnic-cultural markers as it exerts representation by using an indigenous radio station, and was voiced by an indigenous announcer, valuing cultural ties of tribe, community and ethnic group (Morigi et al., 2013). The audio message was also shared via WhatsApp.

We can observe the use of technological means of communication as an exercise of autonomy in community actions. It also indicates a clear intercultural dialogue without minimizing or reducing the expression of the traditional community's identity. According to Silva and Kuhn (2017), 
contemporary forms of technological communication such as the internet or applications can aid both in the acquisition of knowledge and in the expansion and registration of indigenous traditions. Therefore, it also functions as a way of re-encountering and valuing these expressions and not as a way of annihilating identity that interferes with the process of legitimacy of indigenous populations in the city. Artifacts associated with the "urbanized" world can be embedded in non-Western cultures, and act as an aggregator of the community with other indigenous people and other people in general. In a city environment, therefore, we understand the integration of these new devices as a means of guaranteeing livelihood and subsistence, considering, for example, the fact that this allows proximity to peers.

On the day of the event, caxiri (a typical indigenous alcoholical beverage) and rapé (a very fine, snuff-like powder, introduced into the nostrils by sniffing it through hollow tubes, that indigenous peoples claim has medicinal and mystical properties, often used in healing rituals of body, mind and spirit) were offered to the participants. The festival was held on a Saturday at the "Tent", a reference point for the community. It is an open space, covered by a roof, and with chairs arranged in a circle, in which all SRC activities take place. The activities were divided in to three sections: in the morning there was a co-operative game with the children of the community in which we noticed an expressive participation of the local children, some of whom were accompanied by their parents as spectators. At noon, there was lunch with typical food and drink prepared by the indigenous people of SRC and funded by the LABINS team. In the afternoon there were music and dance performances held by two invited indigenous groups of other communities: the first with traditional flutes (Bayaruá group) and the other with an indigenous music rock band (Waruna Kokama group). We saw about 15 (indigenous and non-indigenous) residents of the settlement attending, in addition there were about 20 other visitors. In comparison, other activities already carried out in the community, such as health and leisure activities promoted by the Catholic Church, might have around 100 people attending. Below we make some hypothoses about the low but significant participation at the Meeting of Ethnic Groups. Among the indigenous people who wore clothing and accessories corresponding to their indigenous traditions were the cacique, the deputy cacique and his family, several children and guests from other settlements.

In the middle of a speech, the cacique spoke about the group organization necessary for the accomplishment of the event. Despite a prior impression that we had about the lack of community involvement with the event, leadership reports emphasized the active participation of indigenous communities in the production of food and beverages, as well as collaborating to provide dishes, cutlery, tables and chairs. We find it important to emphasize this aspect. Much of the involvement with community causes is assessed through visible presence. However, we also understand the importance of considering another form of participation that is "behind the scenes" involvement. In addition to face-to-face activism, it is important to evaluate the modes of participation and solidarity bonds through non-face-to-face collaborative activities, in pursuit of a common goal (Nepomuceno, Brito, \& Góis, 2009) describe. This dimension is established through co-operative practice and dialogue on community issues. The authors understand participation as a social concept of the individual, who assumes the ability to be present in a collective process for the change of a reality. Thus, we understand that there may be many activities related to participation that are not strictly linked to attendance, at association meetings, for example.

However, the expressive absence of residents during the Meeting of Ethnic Groups, and in the daily struggles of the community is a fact that must assume importance when considering the community relations of SRC. This does not disregard the potential of the residents' participation in secondary activities or in supporting the main issues, which is also indispensable in the maintenance and promotion of community engagements and struggles. Perhaps the lack of solid relationship between indigenous and non-indigenous communities is connected to the levels of absence and non participation on the day.

Ioris (2011) affirms that the past of indigenous peoples returns and reaffirms itself with the execution of traditions and cultures, constituting a great mobilization in the process of ethnic reaffirmation. Considering this point, the intervention carried out by the Meeting of Ethnic Groups allowed the participants (those present, and those who took part in the preparations) to re-encounter 
aspects of their culture through music, handicraft exhibitions, production and consumption of traditional food and beverages etc. The intervention through the celebration became a fragment of the cultural traditions of those people, resumed on the day of the event. Whether through narrative, or fragments such as this facilitated by psychosocial intervention, there was a mobilization to return to the origins of ethnicity, in establishing a dialogue between the past and the present of an ethnic group.

\section{Feedback: the impressions of the residents about the Meeting of Ethnic Groups}

In order to get feedback on the results achieved by the Meeting, we conducted interviews with residents, asking: How important was the event to the community? How did the intervention contribute to the promotion of communication among residents? What did it represent for the residents and for the settlement? And in view of the low turn-out of residents on the day of the event, we asked: Why didn't many people participate?

Considering the issue of communication as one of the main problems listed, one positive fact can be identified: that the residents stated that they had been invited to participate in the event.

However, the reports also show that the residents associated the lack of participation in the celebration with a lack of motivation. Some considered that they did not have sufficient involvement to participate in events, promoted by the community, nor with the causes pertinent to this. This appeared mainly linked to the fact that the celebration was considered "indigenous" and had traditional cultural characteristics. The activity did not correspond to the kind of entertainment that appealed to them or with which they identify, also pointing to a lack of deep (non-state defined) relationship building between indigenous and non-indigenous communities. Some other reports justify their absence because of work commitments, however, they claimed to have sent their children and relatives to the activity.

Paradoxically, they considered the event relevant, especially to promote community unity. It is necessary to consider that relationships established between communities and intervention agents, especially those who occupy spaces of power or knowledge, such as university groups, may be marked by actions that express a desire to meet the expectations of the interventioned agent. Thus, the community's potent opinions about the relevance of the event may be a kind of response that expresses the desire to please LABINS' interviewers. According to reports, the main relevance was for the event to draw attention to the existence of the community to the authorities, and thereby highlight the existing problems. Even though the festival was celebrated with predominantly indigenous characteristics, the residents believed that it can represent the community to the principal institutions/governing bodies/organizations, and so bring benefits for all (indigenous and nonindigenous). In addition, even non-indigenous residents understood this intervention as a way to strengthen cultural ties between the existing indigenous ethnic groups. An important observation was made by the mother of the cacique, that even in grassroots communities, it is rare to hold a celebration focused on indigenous traditions. Perhaps there is a common misconception that indigenous grassroots communities exercise their traditional practices more expressively, than the communities in the city.

Another important factor reported was the promotion of mutual support in the production of the beverages and food. According to the report, several residents organized themselves to prepare the food served at the party, demonstrating an attitude of collaboration and commitment. We soon realized that the intervention, in re-encountering aspects of traditional indigenous practices, not only contributed to the strengthening and enhancement of culture, at a macro-level, but also worked on a psychosocial dimension related to the relationships among the people of the community.

The festival brought life to a street normally considered quiet. Later we learned that the event lasted for hours, until dawn. We also noticed that the presence of other invited indigenous groups promoted a process of identification through their interaction, perceived later by the intervention group as being more harmonious than usual. Many residents considered this event of paramount importance to the community, precisely because it made it possible for the locals to be close to other indigenous communities in Manaus. This is considered a way of strengthening the indigenous culture, preventing their customs and traditions from being lost.

According to Góis (1993) Community Psychology aims to develop the consciousness of the residents as historical and community subjects through an interdisciplinary effort that pervades the 
development of groups and community. This transformation from individual to community subject can be perceived by the residents of the community when they say that it is necessary to maintain the unity and that this type of mobilization promotes communication among them.

We understand that although they consider this type of mobilization important for the strengthening of indigenous culture, many residents do not adhere to it because they do not feel they share the same traditions. We think that collective apathy can cause, in the long run, lack of communication among the members of the community, as conceptualized by Góis (2005), affirming that community activity is carried out through co-operation and dialogue, being guided by itself and through meaning and sense. Without this dialogue, a weakening of the movement and its common interests may occur, and may therefore be an obstacle to the achievement of the community's objectives, especially its basic rights (recognition of an indigenous settlement, official supplies of light and water, asphalting of roads etc.).

\section{The rights discourse and postcolonialism}

\section{Reflections}

The process of colonialism has had an impact on indigenous ways of life (Noelli \& Ferreira, 2007). In addition to the historical exploitation of the native territories and their inhabitants, it also reached a cultural and / or scientific dimension, which inferiorized narratives and symbolic representations of indigenous peoples, categorizing them as primitive. Postcolonial studies have made theoretical advances in understanding the oppressions and discriminations that are around the sociocultural differences arising from the colonialist process. However, there is still a question of how the discourses of ethnic-political-cultural minorities can compete with a vast production of thought that collaborates as a support for current economic models. Thus, postcolonialist discussions regarding indigenous identification processes are not seen with due relevance to what should be given to the historical roots of these processes and their impacts.

The relevance of postcolonialist discussions are indeed complex but only make sense in terms of the extent that agency is given to indigenous peoples as a result of these discussions. There seem to be two principal areas of inquiry about how agency can be acquired: The Rights discourse and Decoloniality. If we look at The Rights discourse (e.g. Morgan, 2004) we can see that this inquiry is based on the legal recognition of not only indigenous rights but also the legal recognition of indigenous people, per se. This means that indigenous peoples are having to define themselves in the very state terms that sought to delegitimise and dispossess them of their land in the first place. We especially found this to be case when the cacique in our intervention raised his concerns with what he saw as a gradual loss of indigenous identity, as many of their traditional practices seemed to be disappearing.

Corntassel (2012) goes further to explain that this process of having to define oneself in the terms of the state - which is akin to Du Bois' $(1903$, p. 8) "double consciousness" - is technically and legally underpinned by the UN Declaration on the Rights of Indigenous Peoples' Article 46, part 1 that prohibits any threat to the integrity of a nation's territorial control. Corntassel argues that with Article 46, any demands that are made by indigenous people can be interpreted as a threat to the integrity of the state, if the state's a priori position is that of denial or lack of compromise. This works especially at an insiduous level of resource-exploitation because if the state believes that indigenous rights or their recognition could impede or restrict its expansionist or capital growth potential, Article 46 can be invoked to re-frame any indigenous request for recognition as an existential threat to the state. Seen in this light, indigenous rights are only contingent on state interest not on inherent equality or recognition. This issue was represented in our intervention when some of our participants appeared to show no interest in participating. However, when we dug deeper, we found that this Article 46 tension (cause of the lack engagement) was illustrated by many of our residents who had an interest in maintaining their "territory" (Fernandes, 2009) that includes the cultural practices that go with the land and its management, whilst others were more concerned only with securing the "land" (Gallois, 2004) for housing and development.

\section{Decolonialty}

Quijano (2000) and Mignolo (2002) would both characterise the ethical powers of the state in 
regard to its UN implementation as a 'coloniality of power'. This term encompasses not only the legal powers of state domination but also its power to impose a hegemonic agenda that prescribes which types of knowledge or history is of value and therefore exists within the state's psyche and which types of knowledge that don't. State control of epistemology is crucial because it legitimises its exercise of legal power. Corntassel (2012) describes this exercise of state power as the "politics of distraction" and he sees it as having three components.

Firstly, Corntassel (2012) regards self-identification in state terms (as described previously) as counterproductive because it essentially entails indigenous people being brought under state control. On a grassroots-level in our intervention, we could see that the dynamics between our community residents were uneven because of an implicit denial of their cosmological belief systems and spiritual practices that, in their minds, belonged to their "territory", in favour of a state-definition of "land" for development. We discovered that this underlying "politics of distraction" was at the root of much of the conflict between the community and leadership in our intervention.

Secondly, Reconciliation without actual material (i.e. land and other natural resources) Restitution remains mere lip service because the status quo between the state and indigenous people remain unchanged. As outlined earlier, our residents mentioned many infrastructural problems such as lack of basic sanitation; irregular water and electricity supply; unsurfaced roads; legal ownership of land; accumulation of garbage in open areas, all of which fed into their basic dissatisfaction with state intervention.

Thirdly, only focussing on resources and their management serves to reinforce the belief that market economics are the only way forward for stewarding resources. Corntassel (2012) believes that indigenous acceptance of market economics will also always eventually lead to their exploitation for the reasons enshrined in Article 46, at the expense of indigenous concepts of kinship relationships, as tools of resource stewardship. So, decoloniality as a process of self-determination is therefore about recognising indigenous people and their rights outside of state definitions or its 'coloniality of power'. We found that our residents were given very little choice but to focus on resources and their management because according to the community leadership, the inclusion of non-indigenous communities in their "territory" meant that they were not able to keep the settlement as an indigenous village (for example, keeping it unpaved) with its traditional practices.

In order to recognise indigenous people outside of state definitions, Corntassel (2012) advocates "resurgence" as a form of everyday decolonialism. In taking an ethnophilosophical approach (Mbiti, 1970; Oruka, 1990; Sefa Dei, 2014) to culture, where cultural artifacts such as music, poetry, oral sayings, customs etc. are brought to the fore as principal sites of community knowledge, Corntassel (2012) ascribes to them a subversive political agency:

If colonization is a disconnecting force, then resurgence is about reconnecting with homelands, cultures, and communities. Both decolonization and resurgence facilitate a renewal of our roles and responsibilities as Indigenous peoples to the sustainable praxis of Indigenous livelihoods, food security, community governance, and relationships to the natural world and ceremonial life that enables the transmission of these cultural practices to future generations (p. 97).

Simpson (2008) recommends the following four strategies for implementing Corntassel's ideas around "resurgent" activities:

1. Confront "funding" mentality - It is time to admit that colonizing governments and private corporations are not going to fund our decolonization. In the Meeting of Ethnic Groups, we did begin to touch on this, as we looked at how the community galvanized itself into action to make our celebratory event happen. Our indigenous communities in supplying the food and beverages (caxiri, pororoca, baked and cooked fish, etc.) as well as participating in both the behind the scenes and face to face activities of our intevention in so doing, began to address issues around self sustainability and their own processes of decolonization, as the cacique initiated.

2. Confronting linguistic genocide - There is little recognition or glory attached to it, but without it, we will lose ourselves. The cacique, in bemoaning the loss of cultural tradition, spoke to this very point and made sure that as much indigenous culture was included in our celebratory event as possible.

3. Visioning resurgence - The importance of visioning and dreaming a better future based on our own Indigenous traditions cannot be underestimated. The celebration day was very much about that as it 
was arranged into two sessions; a cooperative game with children from the community who were joined by local children and their parents, as spectators, and an afternoon of community presentations about the future of the community.

4. The need to awaken ancient treaty and diplomatic mechanisms - Renewing our precolonial treaty relationships with contemporary neighbouring Indigenous Nations promotes decolonization and peaceful co-existence, and it builds solidarity among Indigenous Nations. For the celebration day, community leaders invited indigenous parentes (tribal relatives) that included representatives from the Bayaruá and Waruna Kokama communities, who gave performances of the songs and ritual dances.

In view of this, we ponder the need to reflect on the existing indigenist policies, which sometimes seem to crystallize aspects of identity. The policies are often based on the fixed aspect of the needs and characteristics of grassroots communities, disregarding the significant migratory processes that have been taking place for about 70 years in Latin America (Estrada \& García, 2016). This can be confirmed when we perceive the absence of public policies aimed specifically at indigenous groups in a city context. Such policies should consider issues of intercultural dialogue, without denying the affiliation of the groups due to their insertion in, or sharing of, cultural elements of the city. The obligation to correspond to the identity markers crystallized in current policies may result in indigenous people, even in the face of new demands and cultural movements, existing and living in a community that is sometimes romanticized or stereotyped, which in a city context, may not meet the new demands of these groups.

In this regard, we believe that the modifications of infrastructure throughout the SRC may also refer to the adaptations needed for the indigenous ways of life in the context of the city, and are thus re-signified. Guidelines can be reformulated, as in the example of the community roads that had not been surfaced in order to recreate the conditions in the original indigenous settlements. The residents' demand for improved roads also indicates the need for improvements in community access, which would facilitate the use of transportation services, such as ambulance or other services demanded by an urban community.

We can also point to the fact that the perspective of "other," especially of the State, can interfere in the process of occupation and dwelling by the urban indigenous communities. This interference can be understood as another possible result of colonialism, where hierarchical social relations between indigenous and non-indigenous people still prevail, and there is a need for approval and legitimization of ethnic groups from the perspective of the dominant social group.

Considering the identity markers present in a meeting that reunited non-indigenous and different indigenous groups, it is important to highlight the role of the "other's" look in the reaffirmation process. Identity is a social phenomenon and recognition is one of the attributes of the social sphere. The processes of intercultural dialogue lead to transformations of indigenous peoples in these environments, and we need to consider other factors in the process of recognition, which does not only use indigenous accessories or a way of life related to static or stereotyped models. It is vital to take into account the subjective dimension that indigenous people have over their identity and group of belonging, sustained, above all by the maintenance of the different beliefs and ways of social organization of the indigenous groups. This in itself is capable of creating impasses in the intra-ethnic relationships in SRC, as well as hampering the processes of identity and political reaffirmation, based on the new patterns of relationship and infrastructure in the city.

\section{Conclusions}

The establishment of indigenous peoples in urban areas has been marked by diverse processes of exclusion directed at certain ethnic groups and discrimination and stigmatizing of their traditional practices. Considering this, what we perceive as an important part of the social experience of the SRC are difficulties of diverse kinds, but which is expressed as a sense of partial loss of traditional cultural aspects. This loss is associated with the experience of living in an urban area, and possibly facing the demands and tensions that occur from sharing or attempting to adapt to diverse lifestyles.

We realize that one of the results of the historical, ethnic hierarchy that has been forced on indigenous peoples has been a partial departure from many aspects of their traditions and cultures. However, despite the various reconfiguration processes, one important characteristic maintained by 
these peoples in the city is the notion of collectivity which is sustained by the common indigenous ethnic groupings identified in urban areas. Even if largely multi-ethnic, communities ensure the perpetuation of indigenous organizations in the city, as well as being a means of maintaining ties between peers. However, we recognise that this will not happen by itself because the dominant (nonindigenous) cultures within urban areas will always try to colonise (Quijano, 2000; Mignolo, 2002) indigenous cultural expression into assimilation and invisibility, which to a certain degree, we had noticed in our project. So, we would propose that a conscious (intentional) programme of "resurgence" activities (which would include aspects of the process of conscientisation (Freire, 1973) would need to be delivered for all the ethnic groups within the urban environment. In this way, we would be able to move away from the state-defined roles (rights and histories) of the ethnic groups and move towards relationships based on pre-colonial extended kinship ties and shared world views, cosmologies and "territories."

Our intervention with the SRC, based on community social psychology, allowed us to get in touch with the main community and psychosocial problems of this space. We realize that infrastructure and the difficulty of accessing basic rights make social and community life more difficult. This foregrounds the importance of considering the relevance of creating public policies that are based on the reality of indigenous peoples in the city.

In addition to political issues, intercommunal impasses beset by discrimination and prejudice, make the residents' relations with the surrounding population increasingly complex. We see the strong impact this has on indigenous ways of life in the city, which has resulted in a process of identity denial, and made it difficult to engage in their demands, since we understand that this involvement also goes through a process of self-affirmation.

Communication was one of the main issues highlighted. Dialogue and communicating information to the residents could be better facilitated. We perceive many misunderstandings in the residents' discourses, with extremely veiled or unspoken content, which has caused some discomfort to the residents and consequently their distance from community affairs. The divergence of objectives, with regard to the inter-ethnic relationship made possible by the multi -ethnic nature of SRC, as well as its organization and political mobilizations, is evident. However, we realize that even in the face of these divergences, many of the community guidelines are configured, albeit partially, to meet the interests of all residents.

The purpose of the Meeting of Ethnic Groups was to bring the community together with some of its traditions, and to promote interactivity. It was designed and organized by residents and leaders, and functioned as a strategy to stimulate the autonomy of the community based on its potentialities, enabling the awareness of its agency in solving the problem. We understand that community participation was extremely relevant for the effective organization of the event, communication, invitation, organization of the venue and other preparations. We emphasize this whole process not only as a mere union of the residents, but also as a way to promote community mobilization, and to aid in ethnic self-assertion.

Regarding PAR, we began our contacts with the community through the cacique's request for help. As more internal agents (other residents) and external agents (students and teachers) were involved, the process became more complex and it was more difficult to organize activities. However, at no time did we encounter resistance from CAPISOL leaders or residents. There were always good interactions and they were motivated to be involved in the intervention project, as it was important to them to have a University presence working to improve the community. At times there was difficulty due to turf wars between drug traffickers, which prevented some visits and fear among students, teachers and residents. We overcame this by waiting for the community leaders to tell us when to resume work.

It should be noted that, although the celebration was proposed as an intervention action to cope with the most expressive demand verbalized by the leadership and perceived by the team, which was the issue of communication, it did not correspond satisfactorily to what was planned: to generate greater participation among all the community's residents by means of better communication. However, the team understood that the lack of participation does not seem to be due exclusively to issues of communication or lack of interest, but seems to relate to more complex levels involving the processes of identity in multi-ethnic spaces. This seems to be the factor associated with non- 
participation in community meetings and mobilizations, since many guidelines are based on the rights of indigenous peoples, an identity that many residents no longer associate with.

We agree that the organizational change of the community, which needs to adapt to the way of living in city environments, is inevitable. However, we find that these adaptations have brought with them significant processes of changing their cultural changing their cultural practices. This has been detrimental to the knowledge about traditional practices which tend to be lost due to dominant ethnic patterns, prejudice, stigma or questions of political rights. We believe that it is extremely important to guarantee spaces for dialogues and experiences for the implementation of indigenous ways of life in the city, not only considering their transformations, but also understanding the importance for the perpetuation of traditional practices.

We conclude that the community, through a celebration like this made effective by the intervention, achieved the sharing of stories, experiences, and made visible the presence and resistance of the indigenous peoples in the city. The promotion of spaces such as this can be of great relevance in improving community relations, allowing not only a space for dialogue - and for strengthening struggles by considering possible partnerships with other settlements - but also, an environment for uplifting and re-encountering their ways of life and habits.

We think that the role of the university in this community, and in this case, the proposed intervention, was to facilitate and/or collaborate to reflect the potential of SRC. The indicators of Human Well-being for Traditional Peoples (Lacerda \& Acosta, 2017) point to an important axis for considering the intervention, which refers to "autonomous cultural management". This indicator defines that one of the important aspects for the maintenance and promotion of well-being, is the guarantee of celebrations and traditional practices in a self-managed way. In this sense, we understand SRC's capacity in this process, but that it is not often recognized by its own residents, thus allowing a way for the intervention team to act in this reflexive dynamic. It was therefore important to stimulate the exercise of autonomy to manage the community: the realization of the possibility and capacity to lead its space, and to promote effective actions, in favor of community struggles and the guarantee of the perpetuation of their traditional practices.

One the limitations of the present study was the lack of sociodemographic data about the SRC population making it difficult to comprehend in a more objective way the general demands that the residents experienced. However, the duration of the interventionist group's placement in the community did not allow for such a survey. We note, however, the need for the public services or institutes for population and housing to carry out a more precise survey of the socioeconomic and structural conditions to which the more than 600 inhabitants of this locality are subject. In this way the history of relegating the traditional peoples of Latin America to conditions of vulnerability and extreme poverty will be discontinued. 


\section{References}

Bernal, R. J. (2009). Índios urbanos: processo de reconformação das identidades étnicas indigenas em Manaus [Urban Indians: process of reconfiguration of indigenous ethnic identities in Manaus]. Manaus: Edua, Faculdade Salesiana Dom Bosco.

Bojić, M. (2015). Memória cultural e identidade em Milton Hatoum [Cultural memory and identity in Milton Hatoum]. SRAZ LX, 60, 145-163. Retrieved from

https://hrcak.srce.hr/168208

Brasil. (2012). Lei $n^{o} 12.651$ de 25 de maio de 2012 [Law no 12.651 of 25th may, 2012]. Retrieved from http://www.planalto.gov.br/ccivil_03/_ato20112014/2012/lei/112651.htm

Câmara, S. G. (2008). Compromisso, participação, poder e fortalecimento comunitário: à procura de um lugar no mundo [Commitment, participation, power and community empowerment: looking for a place in the world]. In M. Dimenstein (Org.), Psicologia social comunitária: aportes teóricos e metodológicos [Community Social Psychology: theoretical and methodological contributions] (pp. 43-58). Natal: EDUFRN.

Corntassel, J. (2012). Re-envisioning resurgence: Indigenous pathways to decolonization and sustainable self-determination. Decolonization: Indigeneity, Education and Society, 1(1), 86-101.

Du Bois, W. (1903). The Souls of Black Folk: Essays and Sketches (2nd ed.). Chicago: A. C. McClurg \& Co.

Estrada, A. V., \& García, K. R. (2016). La comunidad sin fronteras. Lengua e identidad entre los ñäñho-urbanos de la ciudad de Querétaro [The community without borders. Language and identity among the ñäñho-urban of the city of Querétaro]. Gazeta de Antropología, 32(1), 1-14. Retrieved from http://hdl.handle.net/10481/42872

Fernandes, M. R. L. (2009). Etnicidade e territorialização: um estudo da política indígena mura em Autazes, Amazônia Central [Ethnicity and territorialization: a study of Mura indigenous politics in Autazes, Central Amazonia] (Master dissertation). Instituto de Ciências e Letras, Universidade Federal do Amazonas, Manaus, AM, Brasil.

Ferreira, M. S. (2019). Indígenas em contexto de cidade: um estudo sobre o processo psicopolitico das dimensões da identidade coletiva em moradores da Comunidade Sol Nascente [Indigenous people in a city context: a study on the psychopolitical process of the dimensions of collective identity in residents of Sunrise Community] (Master dissertation). Faculdade de Psicologia, Universidade Federal do Amazonas, Manaus, AM, Brasil.

Freire, P. (1973). Pedagogy of the oppressed. New York: Seabury Press.

Freitas, M. F. Q. (1998). Inserção na comunidade e análise de necessidades: reflexões sobre a prática do psicólogo [Insertion in the community and analysis of needs: thoughts on the practice of the psychologist]. Psicologia Reflexão e Crítica, Porto Alegre, 11(1), 175 189. http://dx.doi.org/10.1590/S0102-79721998000100011

Freitas, M. F. Q. (2003). Psychosocial practices and community dynamics: Meanings and possibilities of advance from the perspective of the engaged social actors. The International Journal of Critical Psychology, 9, 107-124.

Gallois, D. T. (2004). Terras ocupadas? Territórios? Territorialidades? [Occupied lands? Territories? Territorialities?] In F. Ricardo (Org.), Terras indigenas e Unidades de Conservação da Natureza: o desafio das sobreposições territoriais [Indigenous lands and protected areas: the challenge of territorial overlaps] (pp. 37-41). São Paulo: Instituto Socioambiental.

Góis, C. W. L. (1993). Noções de Psicologia Comunitária [Notions of Community Psychology]. Fortaleza: Edições UFC.

Góis, C. W. L. (2005). Psicologia comunitária: atividade e consciência [Community 
Psychology: ativity and consciousness]. Fortaleza: Instituto Paulo Freire de Estudos Psicossociais.

Higuchi, M. I. G., Calegare, M. G. A., \& Freitas, C. C. (2013). Socialidade e espacialidade nas comunidades de Unidades de Conservação no Amazonas [Sociality and spatiality in the communities of protected areas in Amazonas]. In M. I. G. Higuchi, C. C. Freitas, \& N. Higuchi. (Orgs.). Morar e Viver em Unidades de Conservação no Amazonas: considerações socioambientais para os planos de manejo [Dwelling and Living in protected areas in Amazonas: socio-environmental considerations for management plans] (pp. 23-62.) Manaus: INPA.

Ioris, E. (2011). Fragmentos que fazem diferença: narrativas indígenas na reconstrução do passado e das identidades étnicas [Fragments that make a difference: indigenous narratives in the reconstruction of the past and ethnic identities]. Antropologia em primeira mão, 125(5), 1-17.

Lacerda, L. F. B., \& Acosta, L. E. (2017). Indicadores de Bem-estar Humano para Povos Tradicionais: o caso de uma comunidade ribeirinha na fronteira da Amazônia brasileira [Human Well-being Indicators for Traditional Peoples: the case of a riverine community on the border of the Brazilian Amazon]. Ciências Sociais Unisinos, 53(1), 100-111. http://dx.doi.10.4013/csu.2017.53.1.10

Mbiti, J. S. (1970). African Religions and Philosophy. London: Heinemann.

Mignolo, W. (2002). The Geopolitics of Knowledge and the Colonial Difference. South Atlantic Quarterly, 101(1), 57-96.

Montero, M., Sonn, C. C., \& Burton, M. (2017). Community psychology and liberation psychology: A creative synergy for an ethical and transformative praxis. In M. A. Bond, I. Serrano-García, C. B. Keys, \& M. Shinn (Eds.), APA handbook of community psychology: Theoretical foundations, core concepts, and emerging challenges (Vol. 1, pp. 149-167). Washington, DC, US: American Psychological Association.

Morgan, R. (2004). Advancing Indigenous at the United Nations: Strategic Framing and its impact on the normative development of International Law. Social and Legal Studies, 13(4), 481-500.

Morigi, V. J., Laroque, L. F., Magalhães, N. M. E., Gomes, C. R. A. S., \& Barden, J. E. (2013). Memória cultural na construção das identidades e mapas imaginários de práticas culturais étnicas [Cultural memory in the construction of identities and imaginary maps of ethnic cultural practices]. Memória Cultural, 5(10), 186-208.

Nepomuceno, L. B., Brito, A. V. de, \& Góis, C. W. L. (2009). Dialogando com lideranças comunitárias sobre participação: um estudo sócio-psicológico [Dialoguing with community leaders about participation: a socio-psychological study]. Sanare, 8(1), 7485.

Noelli, F. S., \& Ferreira, L. M. (2007). A persistência da teoria da degeneração indígena e do colonialismo nos fundamentos da arqueologia brasileira [The persistence of the theory of indigenous degeneration and colonialism within the theoretical foundations of Brazilian archeology]. História, Ciências, Saúde, 14(4), 1239-1264. http://dx.doi.org/10.1590/S0104-59702007000400008

New Social Cartography of the Amazon. (2018). Movimentos sociais e conflitos nas cidades da Amazônia [Social movements and conflict in the Amazon's cities]. Retrieved from http://novacartografiasocial.com.br/fasciculos/movimentos-sociais-e-conflitos-nascidades-da-amazonia/

Oruka, H. O. (1990). Sage Philosophy: Indigenous Thinkers and Modern Debate on African Philosophy. Leiden \& New York: E.J., Brill.

Quijano, A. (2000). Coloniality of Power and Eurocentrism in Latin America. International 
Sociology, 15(2), 215-232.

Rosa, M. M. (2016). Catarinas e Iracemas: sobre casamentos interétnicos de mulheres indigenas em Manaus [Catarinas and Iracemas: on interethnic marriages of indigenous women in Manaus] (Master dissertation). Museu Nacional, Universidade Federal do Rio de Janeiro, Rio de Janeiro.

Sefa Dei, G. (2014). Indigenizing the curriculum: The case of the African university. In G. Emeagwali, \& G. J. Sefa Dei (Eds.), African Indigenous Knowledge and the Disciplines (pp. 165-180). Rotterdam/Boston/Tapei: Sense Publishers.

Silva, R. H. da; Kuhn, N., Jr. (2017, October). Ampliação dos contextos interativos e o seu efeito na identidade cultural indigena MBYÀ-GUARANI da aldeia "YAKÃ JÚ" de Santo Angelo/RS [Extension of the interactive contexts and their effect on the MBYAGUARANI indigenous cultural identity of the "YAKÃ JU'" village of Santo Angelo / RS]. Paper presented at XXII Jornada de Pesquisa, Salão do Conhecimento do Unijuí: a matemática está em tudo. Rio Grande do Sul, RS, Brasil. Retrieved from: https://publicacoeseventos.unijui.edu.br/index.php/salaoconhecimento/article/view/7761 Simpson, L. (2008). Our elder brothers: The lifeblood of resurgence. In L. Simpson (Ed.), Lighting the eighth fire (pp. 73-88). Winnipeg: Arbeiter Ring Publishing.

Souza, N. M. B. (2013, November). A cidade de Manaus-AM e a negação da origem indigena: primeiras aproximações [The city of Manaus-AM and the denial of indigenous origin: first approximations]. Paper presented at I Seminário Internacional: a cidade neoliberal na América Latina: desafios teóricos e políticos. Rio de Janeiro, RJ, Brasil. Paper retrieved from http://www.observatoriodasmetropoles.net/download/relateur2013/norma_maria_bentes_ de_sousa.pdf 